\title{
REVERSE CARNIVAL, REACTIONARY LAUGHTER: CRITIQUE OF AN INTERMISSION
}

\author{
Arbeen Acuña \\ University of the Philippines Diliman \\ arbeen.acuna@gmail.com
}

\begin{abstract}
About the Author
Tilde (Arbeen Regalado Acuña) is an MA Araling Pilipino student at the Departamento ng Filipino at Panitikan ng Pilipinas, University of the Philippines-Diliman. He graduated from the University of the Philippines-Los Baños and received fellowships to national workshops for creative and critical writing. Kritika Kultura, Likhaan, Tomas, UP Forum, Ani, Pingkian, High Chair, DiscLab, and Bulatlat, among others, have published his work.
\end{abstract}


Literary analysis of an un-literary text posturing as entertainment, pestering the worn-out minds of unsuspecting participants, watering down critical issues threatening the security of tenure and the unity of the work forces of the University was what was on my mind, begging to be written, as I watched an intermission number that was no more than a cheap show meant to pull funny bones out of the audience and kill them off eventually. I woke up inside a nightmare that started with me among the "unofficial" delegates literally situated at the margins of an administrative staff conference for the University's employees.

A "script," provided by the vice president for administration ( $\mathrm{VP}_{4} \mathrm{~A}$ ) that was acted out by "official" participants went like this: "Wilma, an administrative officer, has caught Edgar several times doing his private business in office during office hours using the office computer-selling his goods online. When Edgar failed to perform a task, Wilma immediately confronted Edgar that the reason for his failure to deliver was because of his allegedly illegal business at the office. Edgar confronted that Wilma is picking on him due to her (sic) being active in union activities."

Two groups were tasked to perform a skit based on the award- or rather, meritwinning script, but they were encouraged to improvise, for maximum entertainment showcase. One group portrayed Edgar as someone with multiple rackets: from online sari-sari store to offline supermarkets, and other sorts of businesses done within office hours. The other Edgar was mocked by Wilma, telling him that being under salary grade 1 does not permit him to do "personal" things inside the office. One Wilma requests Edgar to finish the attendance report, which he failed to accomplish even after one rating period (6 months) Upon confrontation, the other Edgar argues with Wilma that he is busy with union activities, while the truth is-as far as the skit is concerned-the delinquent subordinate is not really attending to union duties, but is, in fact, trying to make ends meet by earning elsewhere (stalls) and nowhere (cyberspace) during office hours. In between the exaggerated laziness of the employee posing as an active union member, and law- and order- and justiceabiding supervisor-as far as the skit is concerned-is laughter.

Wilmas are self-righteous pricks picking on Edgars, who are subordinates meant to follow orders and promise that they will not repeat the wrongs they admit to having committed. Conflicts will end when Edgars cooperate with Wilmas, as the former merely see a superficial aspect of the whole office operations, while the latter perceive the bigger picture. This is what the tandem of the script and the skit executing the script inculcates in the minds of the seemingly incognizant audience. 
The hahahahas heard in the halls are as poisonous, if not more dangerous, than the discussion of management policies. Such a subtle attack against the union is sinister, as the covert tirade seems to drape itself in fun and humor-and anyone who doesn't get the punchlines or who doesn't find the jokes funny are either persons with no sense of humor or snobs with no time for crass entertainment. Iconfess $I$ maybe boxed with the latter eategory, wait, who eares about such eonfessions. This essay is an attempt to reach out fellow workers and elaborate on how such a show is distasteful and such cheap humor is of the lowest of the low. To be particular, it is reactionary propaganda camouflaged in smiles and giggles that in effect robs the dispossessed of tools for dissent that was once taken back by the lower class: the so-called Bakhtinian laughter.

The said portion of the program projects itself as an ice breaker or a light moment of the three-day conference featuring management policies the University had wanted to implement, with the consent of its employees. Whether such consent is informed or otherwise matters not, as long as requisite formalities for shepherding these sheep are accomplished. Thus, this has resulted in the significance of the intermission in the over-all design of the conference in particular on one hand, and, on the other, the administration's grand design for the rationalization of the University's workforce in general; all these efforts in the University's attempts to compete with other universities crushing one another's skulls, and scholastically dragging one another's corpses in a competitive neoliberal arena.

The tournament for greatness and honor and excellence is currently being done with controlled finesse, in as collegial a manner as possible among colleagues. Since the employees are not really colleagues but mga kuya and mga ate and not sirs and ma'ms, as they are non-academic staff meant for clerical and operational work, pushing them to performance level requires a precise amount of condescension, ample dosages of charity, and a technique to ensure that the formula corresponds to the chemistry of the servants or service providers meant to be respectfully exploited.

Thus, the orchestration of this conference that tries castrating the union, with quasi-militant union leaders: the ones that help engineer an efficient machine manufacturing cheap zombie employees: the ones that join the employers in trumpeting rewards only for "top" słaves performers, rewards which were not really rewarded by the Master but granted to quell the impending anger of the dispossessed and to push them back to certain spaces: the ones where undead hirelings can work and serve their purpose of being cogs of the said machine: the one destined not just for greatness, not just for shaping minds that shape the nation, but also 
for unleashing neoliberal slogans: the ammunition that the machine amplifies as moral-wrecking shouts at perceived enemies and to shatter any opposition into fragmented yet organized submission.

$* * *$

Among the hassles to public-private collaborative plunder in the war for the minds of the nation through formation of public opinion is a genuine union struggling for the objective interests of the concerned sector. The union is then to be attacked directly and indirectly. The majority of the talks in the conference are a mix of direct and indirect assaults against collective action, and focus on individual performance, against unionism because some management policies and benefits packages are decorated ticking time-bombs that will reduce the workers' unity into smithereens.

The prettified early retirement package is gunpowder mixed with whatever enlightening beverage one can muster in order to reach a high that is neither nirvana nor enlightenment but the state of intoxication. The Master says that he pities old employees who are too weak to travel to work. He authors these employee characters as fragile, ailing ones eager to retire at the soonest time possible so they can enjoy what is left of their lives. The aim of such a move, needless to say, is to decrease the number of regular workers, to replace them later with contractual laborers, to weaken and eventually bust the union and to diminish the expenses for the benefits supposedly enjoyed by the staff. In sum, a fiction repeated a number of times in a number of talks - such as the conference being dissed and cussed - to preach rationalization, in the noble, infallible, un-dogmatic spirit of neoliberalism.

We find a certain democratic space for limited dissent in Bakhtin's carnival, where subversive laughter is directed against the so-called "official" culture, propagated by the ruling class.

In ennobling the grotesque, a diatribe is directed against the sacred or the spirit, in an act of edifying the body or the flesh over the soul. Such is an assault on and against dominating power in general, and the Church in particular.

The common or "unofficial" individuals composing the horde disdained by elite are disenfranchised when the somewhat illusory space for comedy versus the authorities is confiscated. 
With the carnival reversed-retrograded?-regressed?-laughter is co-opted into a repressive and reactionary tool of those who pride themselves custodians of order.

At the conference being discussed, the "unofficial," i.e., the non-academic horde of employees, is officially represented by ones deemed aggressive enough to attack fellow workers and tame enough to nod and to not engage in sober discourse or otherwise with the administration-as far as the planners and stage managers are concerned. However, they were proven wrong when the audience read between the lines of the fictional, hypothetical, but politically-charged intermission and these spectators later registered their suspicion and inquiries during the open forum:

If it took the supervisor six months to reprimand and to not extend a helping hand to a subordinate tasked to do a simple task, then the supervisor might also be doing some monkey business on the side. If the employee painted as delinquent tries to make ends meet, then the salary might be less than what his family needs, thus the personal is not just political but also economic. If the Edgars are using union activities as an excuse, then they should have apologized not just for deceiving their supervisors but also for using the union as a rather inconvenient scapegoat. Inconvenient, since it is quite appalling that these Edgars penned by $\mathrm{VP} 4 \mathrm{~A}$ are being assholes (apologies for lack of a better term). If the Wilmas somewhat bully or power-trip on the Edgars for their alleged participation in union activities more than their racketeering, then Wilmas should not prohibit union participation and cast a negative light on employees engaged in such activities. But these Edgars penned by VP4A commit a heinous crime, a double jeopardy against the union in two ways: first, by not participating in collective efforts that give them their economic and political benefits, and secondly, by pretending that they are participating in collective efforts that give them and the Wilmas their economic and political benefits. These Edgars are worse than Wilmas, who are just guilty of the first item, as these Wilmas are often being thankless douchebags (again, apologies for lack of a better term) every time they reprimand union members doing their duty to serve all the employees of the University.

Both versions end with the Edgars apologizing for their inefficiency, while the Wilmas forgive the indolence, as if the delinquencies were the fault of the employees alone - something that contradicts the managerial policies being tackled, which preaches "mentoring" and the quasi-care of the University's cogs and screws and engines that run its operation. The intermission implies that grievances will end harmoniously if the subordinate succumbs respectfully to the supervisor, who can say whatever she wants so that the office can achieve its targets. The supervisor is then immune from scrutiny and castigation, since they are the mentors, and if the mentees do not learn, it is never the mentors' fault. 
Looking at the bigger picture, the $\mathrm{VP}_{4} \mathrm{~A}$ deviated from the topic assigned to him so that he can zoom into a smaller, more trivial (but not really insignificant) snapshot. The VP4A was tasked to share experiences and practices in handling grievances, which are usually filed by those at the bottom of the food chain against the top cats up at the bureaucratic hierarchy such as the VP4A. In the script and in the skits executed, Edgars hold no real grounds for grievance, make excuses, and insist for a higher rating, while Wilmas wield the sword of justice, remain principled, stand by the "unsatisfactory" rating for the Edgars, who have not performed well enough for the standards of the office.

Edgars, i.e. the proud delinquent complainants who later admit indolence a la Juan Tamad, serve as the laughing stock who end up with white flags of confession and repentance. They also end up pledging allegiance to the supervisors, who in turn are loyal to the highest of the gods of the University. The sacrilegious becomes the joke, and Bakhtin rolls in his grave-moreover, this is not due to genuine laughter but perhaps with sighs of frustration in between, especially because the VP4A is a professor specializing on labor relations-yet the school he subscribes to seems to subscribe in return to the idealist and romantic notion of labor-and-capital harmony-something possible if labor admits its fault of being too demanding as capital toils and works hard for the future of the world and the good of all mankind.

Such is the danger of comedy where, as Alenka Zupancic has stated, "the subject is universal." Using Edgars as a representation of complainants invalidates any grievance or administrative complaints, and thus implies that workers are just being whiners each time they complain; that they do not work on solutions, being the brats that they are. Such is the point of the three-day conference: the administration, through the office of the Staff Regent, wants the employees to stop thinking and to work in positive vibes with the management toward the vision of the University created by the gods in the Hall up at the High Chambers. On the other hand, Wilmas shall implement the law of policing the constituents or shepherding them into submission, to make possible a hassle-free, commercialized, free-market, internationalized education with dreams of contractualizing and cheapening labor for the sake of the happiness of the capital.

Additionally, perks are offered to and accepted by people who will cooperateincluding, but not limited to, not just racketeering within office hours, but profiteering from private-public ventures facilitated by University offices. Why earn on the side in hiding, when one can earn more with official papers and documents and claim "public service" for doing so? Why conduct online retailselling, when one can sell assets, succumb to state abandonment, save the 
government from its responsibilities, and lessen the headache of the figureheads of this third-world country doomed to subservience? Why tread a path to success, when one can connect and rise up the ladder through connections? To pursue the latter possibilities posed by the barrage of rhetorical questions, one must obey first before one complains, and, in the process, attack anyone who complains. Potential complainants were reduced to being "unofficial" delegates such as yours truly so that they can be silenced and stripped of the right to speak right from the very beginning.

The show is never possible without stage managers and production staff, eooperative with the Masters, barking at intruders, treating them like mailmen delivering letters that tarnish the hand that feeds the eanine army. There too are masterminds, under the payroll of an exelusive, imported, expensive, i.e. at the expense of other people, dog food from the Master that cosplays too as the dog that he is, so he can integrate with his masterminds who think they are at equal footing with the Master, who of course, has another master up the power ladder. Collaboration with ones wearing progressive masks beeause they once were progressive is the tactic employed by Masters and masterminds to gain and to aceess and to snateh goods, which are supposedly meant for everyone, for themselves and their exclusive circle.

Such is the involvement of $\mathrm{VP} 4 \mathrm{~A}$, who was one of the founding members of the union. At the time when the master of the University is not yet the Master but a mastermind himself vacillating between contending forces, VP4A was assigned $\forall P_{4} \mathrm{~A}$ due to a tactical [d]alliance that was proven to be viable and possible and beneficial to concerned parties at that time. Such tactical alliances emerge upon being faced with a greater enemy. Lesser forces combine, needless to say. VP4A beeame $\mathrm{VP}_{4} \mathrm{~A}$ due to a sort of negotiation between the master who was yet to be Master, so a sure fire victory against a greater evil may be [elaimed?], at that moment. The [d]alliance was the sanest thing to do at that moment, and the problems arising at this moment was among the risks already considered a possibility at the time both parties decided to form the [d]alliance.

Reeruited too to the dark side is Mister Bee, who was as busy and as effreient as a hard-workingbee, whoonce helped edueatinghis fellow worker drones, whoserved as a role model to the youth during his olde days, who now serves at the pleasure of the Master, making sure that every bidding is executed up to the metieulous detail. Being the shadow mastermind of the conference, he merely gestures as a maffa leader, and his underlings do most of the dirty work. Mister Bee used to wear socks under his sandals. Now, the socks are removed, which implies that he is being 
serious with shit. And once he is compelled to speak up and take siege of the stage, the situation of his exclusive cirele's position is eritieal and is "dejado."

Among the minor characters behind the curtains, the most interesting and eonerete is Madame $C$ for Chair. When we were at the margins, a hotel attendant was about to bring stacks of eloth-draped monobloc chairs, upon the request of a eoncerned official delegate. Madame Chair, the wife of national president of the union, trafficked the attendant, shouting at him, telling him that the chairs are needed over there, pointing at an opposite direction, away from us at the margins.

Madame Chair's husband is, of course, a kind of a sock puppet, may be the one that oceasionally warms Mister Bee's feet. Madame-Chair's husband has also been instrumental in certain "trips", of which I would elaborate two: 1) the integration with the pieketing workers of Tanduay and 2) the necessary rally in UP-Baguio. The former was an exeuse so that they ean borrow the van of the union and proceed with the assessment of the Office of the Staff Regent, the office responsible for the staff conference that coopts employees into submission; while the latter was a necessary exeuse so they can use the union's van and avail of the free transportation promo up north in Pagudpud. Cheap tricks veiled with progressive eauses, which make these acts more sick in the brain and the heart.

The reversal of the carnival is made possible when the Master cooperates with a top-caliber organizer (from the "unofficial" lower-class, made up of second-class citizens considered non-academic) that cooperates with a horde of minions at his disposal, ones that are neither cute nor funny at his disposal. A cooperation of one esteemed figurehead makes everything collapse before the altar of the masters. Mister Bee, if you, dear reader went through the text struck out, becomes Master Bestfriend of the administration determined to implement neoliberal trends that he thinks are the new way to innovate the cause he once fought for, perhaps he thinks that his former colleagues in the union who hold on to the militant tradition are passé, and are being old fashioned and whiny about the new, I don't know, who knows?

Stepping back a decade, I find myself about to "graduate" from my freshman status. I was then an iskolar ng bayan, trying to live up to the label by being involved in campaigns so that the label remained true and honest to itself. The usual tirade against "our" camp was similar then and now (if not worse) and could be sum up in the following words: Kayo na ang pinag-aaral, kayo pa ang galit (rough translation: 
You are subsidized, yet you still want more). Mister Bee then is among the ones leading in the front lines.

And now here we are at a time when most iskolar ng bayan is actually the iskolar of their parents, or of private scholarships, or other entities that certainly are not the bayan. Their parents as well as these corporations and agencies that subsidized their education will have the right to demand that the scholars serve the interests of their source of funds. This is empowerment. It is further empowerment of the feudal padrino system through the medieval Filipino value called utang na loob. Biting the hand that feeds is never taken kindly-what more of biting the Hand that distributes: the chauvinist knights-in-shining-armor deciding which damsel in distress gets what size of the budget pie. And of course, the University gets the fairest share since it is the prettiest of them all, with all the poise and elegance and honor and excellence it can muster.

Stepping back to reality, and I find myself working for the same institution, the University that granted me my bachelor's degree. I am now among the kawani ng bayan, trying to live up to the label by being involved in campaigns so that the label remains true and honest to itself. The usual label against "our" camp, similar with the label of any progressive formation, is that of being reklamador (roughly: fault-finder, though the thing is, had the economic benefit being fought for pushed through, everyone gets their share, even the ones branding us as mere reklamadors, but Ihad to put these things in parentheses struck out so it appears like a hesitant whisper of truth that is taboo, beeause naysayers with a sense of entitlement and basked administrative authority might be offended, also, to these eandidate employees of the year who insist on rewarding top performers such as themselves through performance-based bonuses (PBB), I want to ask you, what if the rice-subsidy each regular employee receives is also decided depending on the performance in union negotiations, let us eall it performance-based bigas (PBB)? Maybe only a dozen or three in one unit will reeeive rice subsidy, now, how do you rambling rating-crazed grade-conscious freeriding freeloaders feel about that?). Our camp now excludes Mister Bee, who is now at the other side of the fence, using his mastery of words and gestures and all to attempt to convince us that we are being unreasonable and that his camp is being practical; that his camp represents the clamor of the masses, a clamor that seems to exist merely in his imagination, such as that of the clamor for the early retirement package, to allegedly be considerate to the old and to actually obliterate the age-old workers solidarity he once helped build.

And now, here I am, initially demoralized as a leader my generation once looked up to, who is the leader under the Leader we struggle against. Here I am at a time when the kawani ng bayan remains an iskolar ng bayan learning to be a kawani ng bayan. At this moment, this love-hate, push-pull relationship with the institution is 
what fuels the search for meaning, or meaninglessness, intensity-or lack thereofof class war inside the belly of the state apparatus beast that gives birth to technocrats meant to repair and reform the flawed system of "order," contrary to popular belief and faith that this Moloch forges an army of red flag-waving activists. Logic tells us that the University, as an appendage of the neoliberal state, provokes progressive minds to struggle for change less than it manufactures reactionary elements, as per its initial design, thanks to the Empire.

Competition, as encouraged by "free" market, has been a tool to control and direct the flow of body traffic in the economy. Numerical grades, for students, and performance ratings, for employees, often determine who the universal Moloch prizes so its operations cost less and produce more. Thus, systems of grading are invented to glorify the top performers and ridicule the ones lagging behind. This was one striking element smiting the deprived in the skit being discussed. Edgars, had they been students, might be the ones branded as delinquents, and, due to their bad diction, laughed at by grammar Nazis, and thus they might be implicitly blamed for being what they are.

For emphasis, such a reversal of carnival is sinister, despite its being expected because we are aware of how vacillating this "middle, middling, meddling" class is - the class I identify with and the class I loathe: a love-hate blood-rush that I find healthy so I remain critical and self-critical. Though such complexity is expected of the middle forces that may turn up, down, left, right, I still find it agitating and saddening that such treacherous tricks have been pulled off by people who have once been the champions of the oppressed work force. But, the joke is never on us, it shall always be on them as we will retrieve, repossess, reclaim, and further radicalize and reverse the carnivals reversed. The huling halakhak (last laugh) is ours, we have nothing to lose but barya or loose change.

Despite all these, I chant and end and amen with a Gramscian mantra: pessimism of the mind, optimism of the will. 